\title{
Left Atrial Myxoma
}

\section{A Morphologic and Histogenetic Study}

\author{
Prem Chopra, M.D. and Veena Kumari Sharma, M.D., D.C.P.
}

\begin{abstract}
SUMMARY
Seven cases of excised left atrial myxoma are described. These are compared with organizing and organized thrombi. The tumors occurred at ages ranging from 13 to 48 years with male preponderance. There were distinct histological and histochemical differences between myxomas and thrombi. Myxomas were lobulated, soft and gelatinous. The cells were arranged singly, in syncytium, or in gland like manner and around blood vessels. Scant to abundant acid mucopolysaccharide rich stroma with strong metachromasia was present. The cells on histochemical staining revealed a wide range of differentiation and contained small amounts of neutral mucopolysaccharides. Thrombi, on the other hand, were firm, laminated, and the cells were arranged in several stratified layers. Metachromasia was absent. Neutral polysaccharides were absent within the cells of thrombi, These features support the concept that cardiac myxoma is a neoplasm and arises possibly from multipotential mesenchymal cells.
\end{abstract}

\section{Additinal Indexing Words :}

Thrombus

AARDIAC myxomas have been recognised as a distinct morphologic entity
over 200 years. ${ }^{1)}$ This is a rare tumor, but accounts for $1 / 3$ rd of primary
cardiac neoplasms. ${ }^{2)}$ Most have occurred in the left atrium in relation to the
fossa ovalies, but there is no evidence that the tumors arise from remants of
endocardial myxoid tissue in this region. ${ }^{3)}$ Multiple cardiac myxomas have
also been recorded..$^{4)}$ They may occur at any age, ranging from a stillborn
infant ${ }^{5}$ ) to 95 years, ${ }^{6}{ }^{6}$ but are most frequently found between the ages of 30 to
60 years.
Now that the surgery of the heart and removal of neoplasms has become
a rather commonplace procedure, it appears to be even more important to
recognize the morphologic variants of cardiac myxoma in order to distinguish
them from other cardiac neoplasms of more serious import. Studies have
generally stressed the clinical manifestations of the tumor and rarely have their India.

From the Department of Pathology, All India Institute of Medical Sciences, New Delhi-110029,

Received for publication August 5, 1980. 
morphologic aspects been accorded. ${ }^{81,97}$

In a brief span of 5 years, we encountered 7 cases of this rare tumor. This paper reports a detailed morphologic study of cardiac myxomas and their comparison with thrombi. An attempt will be made for appraisal of their histogenesis.

\section{Materials and Methods}

Seven cases of cardiac myxoma collected in the department of Pathology of the All India Institute of Medical Sciences, New Delhi from 1976 to 1980 were studied. These cases had undergone cardiac surgery for removal of the tumor at this hospital. Paraffin sections were stained with hematoxylin and eosin, and on selected sections from all cases phosphotungstic acid hematoxylin (PTAH), Masson trichrome, Verhoff's Van Gieson (VVG), Wilders reticulin, periodic acid shiff reaction (PAS), iron and toluidine blue stains were performed. Six cases of organizing and organized thrombi were also studied by the above mentioned stains. Tissue from fossa ovalis and from an area nearby was examined from some post mortem cases for the existence of myxomatous "rests".

\section{Results}

Patients ranged in age from 13 to 48 years. There were 5 males and 2 females.

All the tumors encountered by us were located in the left atrium in the region of the atrial septum. The patients were class III to class IV symptomatic and the duration of their complaints ranged between 6-24 months.

All the tumors were lobulated, grayish pink, gelatinous masses varying in dimensions from $5 \times 4 \times 3 \mathrm{~cm}$ to $8 \times 5 \times 2 \mathrm{~cm}$, with the weight varying from 19 to $21 \mathrm{Gm}$. All but one had a stalk which varied in thickness and length from $0.5 \mathrm{~cm}$ to $2 \times 1.5 \times 0.2 \mathrm{~cm}$. The cut surface was smooth or bosselated and was variegated red, gray and yellow. All the tumors were soft and mucoid (Fig. la, b).

The thrombi were grayish brown, opaque, granular, laminated, and firm.

Microscopic features of all tumors were essentially similar, varying principally in the proportion of cells to myxoid intercellular stroma, the amount of fibrous tissue, elastic tissue and the number of vascular channels.

The common cellular denominator in all cases was a round or polygonal cell generally arranged in groups of two or more, in close apposition to capillaries or in irregular compact varying-sized clusters, some times separated from one another by irregular spaces (Fig. 1c). Their nuclei were generally uniform. Mitoses were not noted. The cytoplasm was moderately eosinophilic and was evenly distributed about the nucleus or streaming from one or both 


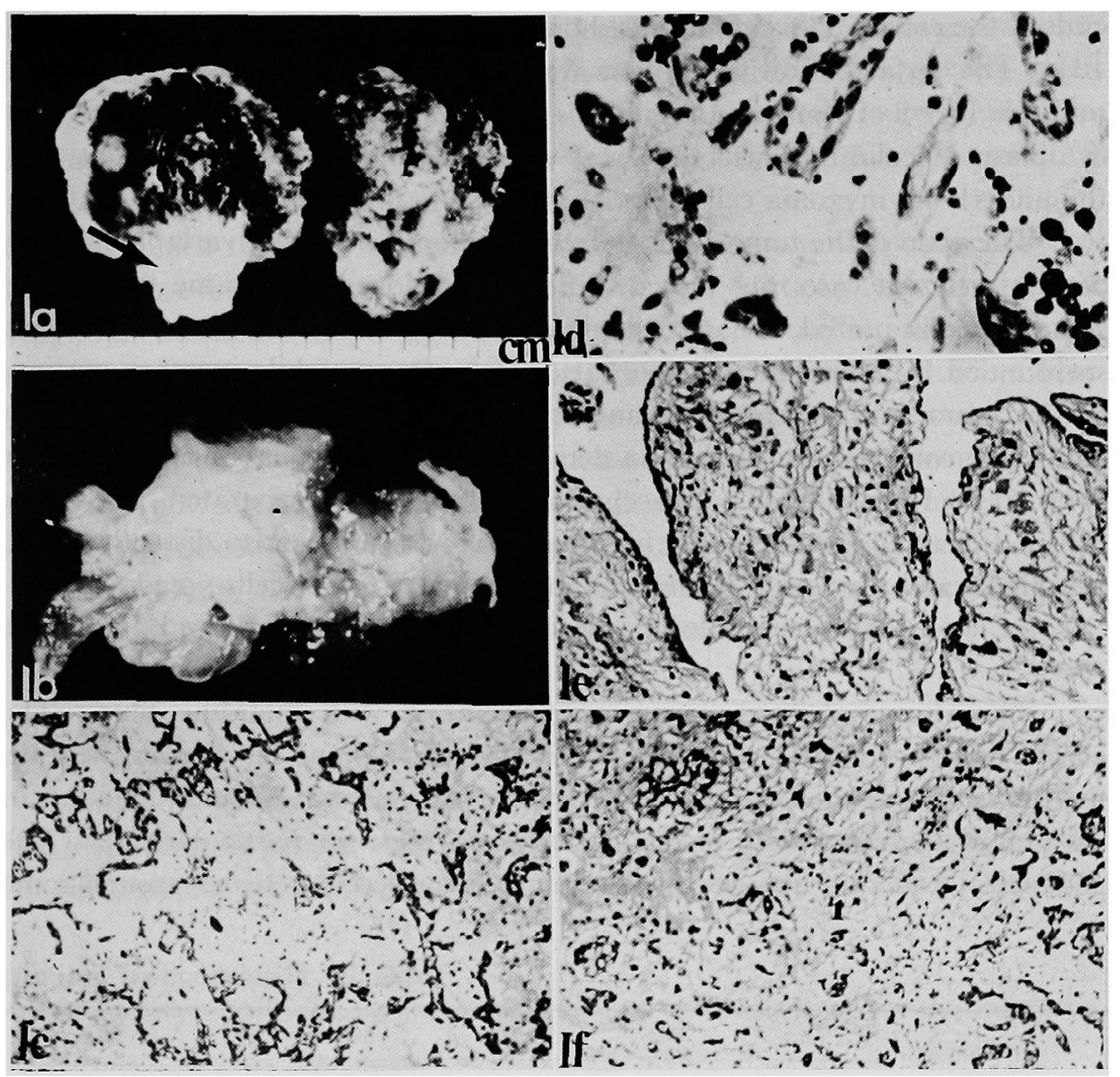

Fig. 1a. Gross specimen of left atrial myxoma. External surface is lobulated, gray white with areas of hemorrhage (right). The cut surface is hemorrhagic (left). Stalk is also seen (arrow).

Fig. 1b. Gross specimen of atrial myxoma of another case. The tumor is gray white, gelatinous and lobulated.

Fig. 1c. Photomicrograph showing tumor cells arranged in groups of two or more and in irregular, varying sized clusters. These are separated by wide expanses of stroma. Hematoxylin and eosin $(\mathrm{HE}) \times 130$.

Fig. 1d. Tumor cells with moderate amount of cytoplasm evenly distributed around the nucleus. Cytoplasmic boundaries are indistinct. Inflammatory cells distributed singly and in small groups in the stroma are also seen $\mathrm{HE} \times 500$.

Fig. le. Photomicrograph showing lobulated pattern of tumor that is lined by single or multiple layers of elongated flattened cells. Note the loose myxomatous stroma. $\mathrm{HE} \times 130$.

Fig. If. Photomicrograph showing tumor cells and loose myxoid stroma. The cells are arranged in an epithelium like and/or gland like manner without a limiting basement membrane. $\mathrm{HE} \times 130$. 
ends of the cells. The cytoplasmic boundaries were frequently indistinct (Fig. 1d). The surface of all the tumors was covered in most areas by a single or multiple layers of elongated flattened cells with long, narrow nuclei and little cytoplasm to columnar cells that were sometimes seen to be in continuity with the underlying myxoma cells (Fig. 1e).

The ratio of the tumor cells to myxoid stroma was quite variable not only among different cases but also in different portions of the same tumor. In some areas, scattered, isolated, single or small groups of myxoma cells were surrounded by abundant polysaccharide rich stroma, while in other portions of the tumor, cells were abundant and assumed an epithelium like and/or gland like configuration without a demonstrable limiting basement membrane (Fig. 1f). Intercellular polysaccharide accumulation separated the tumor cells. Intracytoplasmic mucin in some areas was sufficient to distend the cell cytoplasm and produce a goblet cell appearance. Other cells noted were histiocytes laden with hemosiderin, plasma cells, lymphocytes, and fibroblasts (Fig. lc, d).

The stroma showed strong metachromasia with toluidine blue. The elastic fibers were seen randomly distributed throughout the stroma, beneath the lining and at the base. Collagen fibers were present in small amounts in all tumors, extensive foci of dense collagen were seen particularly near the pedicles. Reticulin fibers formed a sparse but discrete network around some

Table I. Histochemical Staining

\begin{tabular}{|c|c|c|c|c|}
\hline \multirow{2}{*}{$\begin{array}{l}\text { Cardiac } \\
\text { Myxoma }\end{array}$} & \multicolumn{2}{|c|}{ PAS } & \multirow{2}{*}{$\frac{\text { Masson }}{\text { Collagen }}$} & \multirow{2}{*}{$\frac{\text { VVG }}{\text { Elastic tissue }}$} \\
\hline & Cell & Stroma & & \\
\hline Case 1 & + & Negative & t to H & $\begin{array}{l}+ \\
\text { (throughout the } \\
\text { stroma) }\end{array}$ \\
\hline Case 2 & + & Negative & + to $H$ & $\stackrel{+}{\text { (at base) }}$ \\
\hline Case 3 & + & Negative & + to $H$ & $\begin{array}{l}\text { \# } \\
\text { (at surface) }\end{array}$ \\
\hline Case 4 & $H$ & Negative & + to $H$ & $\begin{array}{l}+ \text { to }+ \\
\text { (throughout the } \\
\text { stroma) }\end{array}$ \\
\hline Case 5 & + & Negative & + & $+($ focal $)$ \\
\hline Case 6 & + & Negative & + & $\begin{array}{l}+ \text { (focal) } \\
\text { (throughout the } \\
\text { stroma) }\end{array}$ \\
\hline Case 7 & + & Negative & + to $H$ & $+($ focal $)$ \\
\hline
\end{tabular}


groups of tumor cells. An occasional fiber showed positive staining for muscle in 1 case and in 2 cases, tadpole cells were seen without any cross striations. PAS reaction of the stroma was uniformly negative in all the cases indicating absence of neutral polysaccharides. Contrary to this, positive PAS reaction was seen within the cells (Table I).

Organized thrombi by light microscopy showed several stratified layers of spindle or oval cells, granulation tissue with abundant capillaries, red blood cells, abundant hemosiderin pigment and no mucin. No gland like structures were seen. These were not lined by endocardial covering. Toluidine blue staining revealed complete absence of metachromasia within the stroma. PAS reaction was negative both within the cells as well as the stroma. The latter also showed fine reticulin fibers throughout. PTAH stain was negative. Thick bands of collagen were seen throughout the organized thrombi.

Tissues from the area of fossa ovalis and surrounding area showed loose fibrous tissue but so called myxomatous ' rests' were not seen.

\section{Discussion}

Since the cardiac myxomas were first recognised, a controversy has existed regarding its nature as to whether it is a thrombus or a neoplasm. ${ }^{101,11)}$ The histogenesis of cardiac myxoma and the cellular epithelium-like and

Reaction in Cardiac Myxomas

\begin{tabular}{|c|c|c|c|}
\hline Iron & Reticulin & РTAH & $\begin{array}{l}\text { Toluidine Blue } \\
\text { Metachromasia }\end{array}$ \\
\hline$H$ & + to $H$ & Negative & $\begin{array}{l}+ \text { to } \mathrm{W} \\
\text { (diffuse) }\end{array}$ \\
\hline+ & + to $H$ & Negative & $\begin{array}{l}+ \text { to } H \\
\text { (diffuse) }\end{array}$ \\
\hline+ & + to $H$ & Negative & $\begin{array}{l}\text { H to } H \\
\text { (around groups of cells } \\
\text { mainly) }\end{array}$ \\
\hline H & + to $H$ & $\begin{array}{l}\text { Positive in occasional } \\
\text { cell }\end{array}$ & -do- \\
\hline H & + to $H$ & $\begin{array}{l}\text { Few tadpole cells } \\
\text { No cross striations }\end{array}$ & -do- \\
\hline H & + to $H$ & Negative & -do- \\
\hline+ & + to $H$ & $\begin{array}{l}\text { Few tadpole cells } \\
\text { No cross striations }\end{array}$ & $\begin{array}{l}+ \\
\text { (around groups of cells } \\
\text { mainly) }\end{array}$ \\
\hline
\end{tabular}


gland-like tissues reported in some of the atrial myxomas ${ }^{11)-13)}$ have received little attention. Fine et al (1968) ${ }^{11}$ ) have suggested an endocardial origin of myxoma. They further stated that the accompanying epithelial and glandlike tissues were derived from mesothelium or endoderm. However, the intimate relationship of the two types of tissue and the transition from the typical myxoma to the epithelial and gland like tissue which we have also observed, support a common cell origin as also reported by others. ${ }^{81,91,11,14)}$ The microscopic dissimilarity between the myxoma and mesothelioma of other areas, the absence of basement membrane in the gland-like portions of the myxoma, its endocardial location, and the absence of endodermal structures such as are seen in teratomas, are not in keeping with a mesothelial or endodermal derivation. ${ }^{11}$ An endocardial cell origin appears to be more likely in view of the tissue culture studies. ${ }^{15}$ Silverber and Kay $(1970)^{16)}$ pointed out that myxoma cells contain alkaline phosphatase a finding typical of endothelial tissue, and considered myxomas to be derived from endocardial cells.

By light microscopy, several workers ${ }^{81,11,17)}$ observed the various types of cellular aggregates that we found in this study. Fine $(1968)^{183}$ concluded that myxomas are slow growing tumors that arise from mesenchymal cells. Matsuyama and Ooneda (1967) ${ }^{14}$ found myxomatous tissue not only in the tumor mass, but also in the endocardium and in the muscular layer of the interatrial septum to which the tumor was attached. They also observed a few cross striated, tadpole shaped tumor cells that resembled those observed in embryonal botryoid rhabdomyosarcoma. They considered the cardiac myxoma to be a neoplasm derived from embryonal undifferentiated mesenchyme and thus related to embryonal botryoid rhabdomyosarcoma. However, Fisher and Hellstrom $(1960)^{19)}$ did not find myxomatous ' rests' near the fossa ovalis. Our findings are also in keeping with the latter study.

Merkow et al $(1969)^{20)}$ observed a variety of cellular arrangements in a left atrial myxoma and emphasized the occurrence of vasoformative elements. Electron microscopically, cytoplasm of myxoma cells contained fine filaments that measured from 85 to $125 \AA$ in diameter, and intra and extracellular membrane-bound, elongated, filamentous dense bodies with a periodicity of $80 \AA$. These structure were also observed by others. ${ }^{8), 21), 22)}$ Merkow et al $(1969)^{20)}$ considered the cytoplasmic filaments of 85 to $125 \AA$ as being in the same size range as those of smooth muscle cells. They believed, therefore, that myxoma cells should be classified as a myoid type of endocardial cell. However, others ${ }^{9,16), 21), 22)}$ believed that myxomas represent a benign tumor of the ubiquitous subendothelial vasoformative reserve cell. Numerous studies indicate that, in the early proliferative intimal reserve cell response to injury, the subendothelial smooth cells are characterized by the production of muco- 
polysaccharides. ${ }^{23)-25)}$ According to Ferrans and Roberts (1973) ${ }^{81}$ endothelial cells, fibroblast like cells, macrophages and mature and immature smooth muscle cells are derived from myxoma cells. So, they concluded that cardiac myxomas arise from multipotential mesenchymal cells.

Williams et al $(1970)^{26)}$ suggested that myxoma cells have a secretory function directed towards synthesis of the tumor stroma. They observed that these cells contain numerous cisterns of rough surfaced endoplasmic reticulum, prominent Golgi cisterns and vesicles, and small, single membrane limited bodies with electron dense content. These observations suggest that stromal material is synthesized in the endoplasmic reticulum and Golgi zone, which are known to be the site of synthesis of acid mucopolysaccharides and glycoproteins in other cells, ${ }^{271,28)}$ and that this material is then segregated into membrane bound bodies that function as secretory granules. An alternative explanation for the formation of the stroma is that after synthesis in the endoplasmic reticulum and Golgi zone, the stromal material is transported outsied the cells by the small Golgi vesicles with an electron dense content. ${ }^{8)}$ It must be remembered that the most typical feature of cardiac myxomas is their gelatinous, mucopolysaccharide rich stroma. Unforturately, this stroma does not show any unique ultrastructural features. ${ }^{8)}$ On biochemical analysis of the stroma, ${ }^{29}$ it has been found that myxomas contained approximately $3 \mathrm{mg}$ of hexosamine containing macromolecules per $100 \mathrm{mg}$ dry fat free tissue, out of which about $66 \%$ was glycosaminoglycans. Chondroitin

Table II. Distinguishing Features of Myxoma and Organized Thrombi

\begin{tabular}{|c|c|c|}
\hline Features & Myxoma & Organized thrombus \\
\hline Location & Left atrium & $\begin{array}{l}\text { Ventricles, atrial appendages and } \\
\text { atria }\end{array}$ \\
\hline Gross & $\begin{array}{l}\text { Lobulated, glistening transparent } \\
\text { soft and mucoid }\end{array}$ & $\begin{array}{l}\text { Opaque, granular, firm, lami- } \\
\text { nated }\end{array}$ \\
\hline Surface & Continuous endocardial lining & $\begin{array}{l}\text { Surface not covered by endocar- } \\
\text { dial lining }\end{array}$ \\
\hline Cells & $\begin{array}{l}\text { Variable in number, single or } \\
\text { syncytial, at places forming gland } \\
\text { like structure }\end{array}$ & $\begin{array}{l}\text { Several stratified layers. No gland } \\
\text { formation. }\end{array}$ \\
\hline $\begin{array}{l}\text { Mucin } \\
\text {-stroma } \\
\text {-cells }\end{array}$ & $\begin{array}{l}\text { Abundant, metachromasia } \\
\text { PAS positive }\end{array}$ & $\begin{array}{l}\text { Metachromasia absent } \\
\text { PAS negative }\end{array}$ \\
\hline Elastic fibres & $\begin{array}{l}\text { Thin to moderately thick bundles, } \\
\text { beneath the surface, at the base } \\
\text { and in focal areas in the stroma }\end{array}$ & Few \\
\hline Reticulin fibres & Arranged around groups of cells & Few without any arrangement \\
\hline Collagen & Thin to moderately thick bands. & Thick bands \\
\hline Muscle cells & $\begin{array}{l}\text { Occasional tadpole like cells in } \\
\text { stroma. No cross striation seen }\end{array}$ & Absent \\
\hline Hemosiderin & Moderate to abundant & Variable, scanty \\
\hline
\end{tabular}


4 and/or 6 sulfates were predominant, constituting over $75 \%$ of the total glycosaminoglycans. Hyaluronic acid constituted 16\%. Dermatan sulfate was absent. The high content of chondroitin 4 and/or 6 sulfates and complete absence of dermatan sulfate suggest that cardiac myxomas are neoplastic in nature.

The feature supporting the contention that myxomas (reported here) are neoplastic and not thrombi are presented in Table II.

\section{REFERENCES}

1. Bulkley BH, Hutchins GM: Atrial myxomas. A fifty year review. Am Heart J 97: 639, 1979

2. Mahaim I: Tumeurs et les polypes du coeur. Etude anatomo-clinique, Massen et Cie, Paris, 1945

3. Pritchard RW: Tumours of the heart. Review of the subject and report of one hundred and fifty cases. Arch Pathol 51 : 98, 1951

4. Nichols J, Hennigar G: A case of bilateral multicentric cardiac myxoma. Arch Pathol 67: 24, 1959

5. Reddy DJ, Rao TS, Venkaiah KR, Gupta KG, Devi SP, Naidu NV: Congenital myxomas of the heart. Indian J Paediat 23: 210, 1956

6. Hudson REB: Cardiovascular Pathology, Vol 2, E Arnold Ltd, London, p 1567, 1965

7. Froment R, Gonin A, Delahaye JP, Perrin A, Verneyre H: Tumcurs prinitives du coeur et du pericarde. A propos de 10 observations personelles. Mal Cardiov 4: 519, 1963

8. Ferrans VJ, Roberts WC: Structural features of cardiac myxomas. Histology, histochemistry, and electron microscopy. Human Pathol 4: 111, 1973

9. Stein AA, Mauro J, Thibodeau L, Alley R: The histogenesis of cardiac myxomas. Relation to other proliferative diseases of subendothelial vasoform reserve cells. in Cardiovascular Pathology Decennial, ed by Sheldon C Sommers, Appleton Century-Crofts, New York, p. 245, $1966-1975$

10. Lannigan R: in Cardiac Pathology, Butterworths, London, p. 269, 1966

11. Fine $\mathrm{G}$, Morales A, Horn RC Jr: Cardiac myxoma. A morphologic and histogenetic appraisal. Cancer 22: 1156, 1968

12. Anderson WAD, Dmytryk ET: Primary tumour of the heart containing epithelium like elements. Am J Pathol 22: 337, 1946

13. Honey M, Axelord MA: Intracardiac endodermal heterotopia. Brit Heart J 24: 667, 1962

14. Matsuyama $\mathbf{K}$, Ooneda $\mathrm{G}$ : Histogenesis of primary myxoma of the heart. A case report. Gann 58: 435, 1967

15. Malm JR, Henry JB, Deterling RA Jr: Clinical and pathological study of benign intracardiac tumours; report of a successful removal of a myxoma of the left atrium. Circulation 18: 754,1958

16. Silverber SG, Kay S: Ultrastructure of cardiac myxoma. Am J Clin Pathol 54: 650, 1970

17. Hardin NJ, Wilson JM III, Gray GF, Gay WA Jr: Experience with primary tumours of the heart clinical and pathological study of seventeen cases. Johns Hopkins Med J 134: 141, 1974

18. Fine G: Neoplasms of the pericardium and heart. in Pathology of the Heart and Blood Vessels, ed by Gould SE, Springfield, Illinois, Charles C Thomas, p. 851, 1968

19. Fisher ER, Hellstrom HR: Evidence in support of the neoplastic nature of cardiac myxoma. Am Heart J 60: 630, 1960

20. Merkow LP, Kooros MA, Magovern G, Hayeslip DW, Weikers NJ, Pardo M, Fisher DL: 
Ultrastructure of a cardiac myxoma. Arch Pathol 88: 390, 1969

21. Glasser SP, Bedynek JL, Hall RJ, Hopeman AR, Treasure RL, McAllister HA, Esterly JA, Manion WG, Stanford HS: Left atrial myxoma. Am J Med 50: 113, 1971

22. Kelly M, Bhagwat AG: Ultrastructural features of a recurrent endothelial myxoma of the left atrium. Arch Pathol 93: 219, 1972

23. Bunting $\mathrm{CH}$, Bunting H: Acid mucopolysaccharides of the aorta. Arch Pathol 55: 257, 1953

24. Taylor JE: Role of mucopolysaccharides in the pathogenesis of intimal fibrosis and arteriosclerosis of the human aorta. Am. J Pathol 29: 871, 1953

25. Braunstein H: Histochemical study of adult aorta. Arch Pathol 69: 29, 1960

26. Williams WJ, Jenkins D, Erasmus D: The ultrastructure of cardiac myxoma. Thorax 25: 756,1970

27. Neutra M, Leblond CP: Radioautographic comparison of the uptake of glactose H3 and glucose $\mathrm{H3}$ in the Golgi region of various cells secreting glycoproteins or mucopolysaccharides. J Cell Biol 30: 137, 1966

28. Beams HW, Kessel RG: The Golgi apparatus: structure and function. Internat Rev Cytol 23: 209,1968

29. Bashey RI, Nochumson S: Cardiac myxoma. Biochemical analyses and evidence for its neoplastic nature. NYSJ of Med $79: 29,1979$ 